UDC 633.2-184(497.11)

Original research paper

doi: 10.5937/AASer1846187T

Acta Agriculturae Serbica, Vol. XXIII, 46 (2018); 187-196

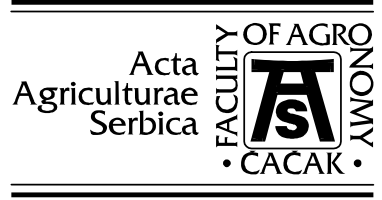

\title{
Productivity of natural grassland of the order Arrhenatheretalia depending on nitrogen fertilization level
}

\author{
Dalibor Tomić ${ }^{1}$, Duško Brković ${ }^{1}$, Vladeta Stevović ${ }^{1}$, Nikola Bokan ${ }^{1}$, \\ Dragan Đurović ${ }^{1}$, Đorđe Lazarevic ${ }^{1}$ \\ ${ }^{1}$ University of Kragujevac, Faculty of Agronomy, Cara Dušana 34, Čačak, \\ Serbia \\ *Corresponding author: dalibort@kg.ac.rs
}

\begin{abstract}
Natural grasslands are major animal feed resources in the moutainous region of Serbia. Proper use of mineral fertilizers in these grasslands can lead to a multiple increase in productivity. The paper analyzes the effect of NPK fertilizers with different levels of nitrogen (unfertilized - $A_{0}$; N60:P40:K40 - $A_{1}$; N100:P40:K40 - $A_{2}$; N140:P40:K40 $A_{3}$ ) on forage yield and botanical composition of natural grassland of the Arrhenatheretalia order on the slopes of Mount Kopaonik. With the increase of the amount of nitrogen applied in spring from 40 to $80 \mathrm{~kg} \mathrm{ha}^{-1}$, forage and hay yields also increased, whereas further increase innitrogen quantity to $120 \mathrm{~kg} \mathrm{ha}^{-1}$ resulted in the absence of the increasing yield trend. In the second cut, there were lower forage and hay yields compared to the first cut. A total of 50 different plant species of 44 genera and 20 families were identified on the grassland. In both cuts, in all fertilized treatments, the grass percentage was significantly higher than the control. The percentage of legumes in the first cut was low, while it significantly decreased in the second crop with the increase in the level of fertilizer. The percentage of other plants was higher in the second cut, as compared to the first one, and it significantly decreased in both cuts with the increase in fertilizer rate.
\end{abstract}

Keywords: botanical composition, fertilization, forage yield, natural grassland

Received 13 July 2018 Accepted 25 September 2018 


\section{Introduction}

In hilly and mountainous regions of the Republic of Serbia, natural grasslands are the most widespread meadow-pasture communities (Lazarević et al., 2009). According to the last agricultural census (2012) (RZS 2013), natural meadows and pastures are present on an area of 713242 ha. According to SGS (2015) in 2014, in the Republic of Serbia, meadows covered 381654 ha, with a total dry matter production of $784111 \mathrm{t}$ and an average dry matter yield of $2.1 \mathrm{t}$ $\mathrm{ha}^{-1}$, and the surface area of pastures was 331589 ha, with a total dry matter production of $561527 \mathrm{t}$ and an average dry matter yield of $1.7 \mathrm{t} \mathrm{ha}{ }^{-1}$. The production of livestock feeds in meadows and pastures is relatively low and unstable, and the main reason for this is the lack of cultural practices (Dubljević, 2007).

The yield and quality of forage mainly depend on the floristic composition of the grassland, the soil, the quantity and distribution of precipitation, thermal conditions and light (Đukić et al., 2008). Under the same conditions, the judicious appropriate use of fertilizers can increase forage yield up to several times (up to $20 \mathrm{t} \mathrm{ha}^{-1}$ ), while at the same time improving the quality of the forage (Stevanović et al. 2004; Nešić et al., 2004; Vučković et al., 2004). Nitrogen is one of the most important nutrients and the most common limiting factor for achieving high yields of natural grasslands (Vitousek and Howarth 1991; Frink et al., 1999; LeBauer and Treseder 2008; You et al., 2017).

The aim of the research was to analyze the influence of NPK fertilizers with different quantities of nitrogen on production characteristics and floristic composition of the natural grassland of the Arrhenatheretalia order.

\section{Materials and methods}

The experiment was designed in 2011, and analyses were carried out in 2016, on the natural meadow of the Arrhenatheretalia order in the village of Rakovac near Jošanička Banja on the slopes of Mount Kopaonik (Serbia) $\left(43^{\circ} 23\right.$ '35,89'N; 2048'29,24'E , $990 \mathrm{~m}$ above sea level). The experiment was set up on a dolomite calcomelanosol soil ( $\mathrm{pH} \mathrm{H}_{2} \mathrm{O} 6.5$ ), which was poor in readily available phosphorus, rich in potassium and moderately supplied with humus. The mean annual air temperature for the given area is $7.9^{\circ} \mathrm{C}$, and the annual rainfall is $771 \mathrm{~mm}$. In 2016, the mean annual temperature was $0.15^{\circ} \mathrm{C}$ lower, and annual rainfall was $249 \mathrm{~mm}$ higher than the long-term average. Monthly rainfall (Figure 1) showed large variations during the growing season (April-September).

The experiment was set up in a completely randomized block design in three replications, with the plot size of $7.5 \mathrm{~m}^{2}(5 \times 1.5 \mathrm{~m})$. The following fertilization treatments were used: $A_{0}$ - unfertilized - control, $A_{1}-$ N60:P40:K40; $A_{2}-$ N100:O40:K40; $A_{3}-$ N140:P40:K40 kg ha-1. Fertilization 
involved introducing the total amount of phosphorus, potassium and most of the nitrogen immediately before the beginning of the growing season, and 20 $\mathrm{kg} \mathrm{ha}^{-1}$ of nitrogen per treatment, except in the control, was left for additional fertilization, which was done after the first cut. In each following years, fertilization was carried out in the same way.

Figure 1. Monthly rainfall distribution for experimental years and 10-year (1992-2002) average

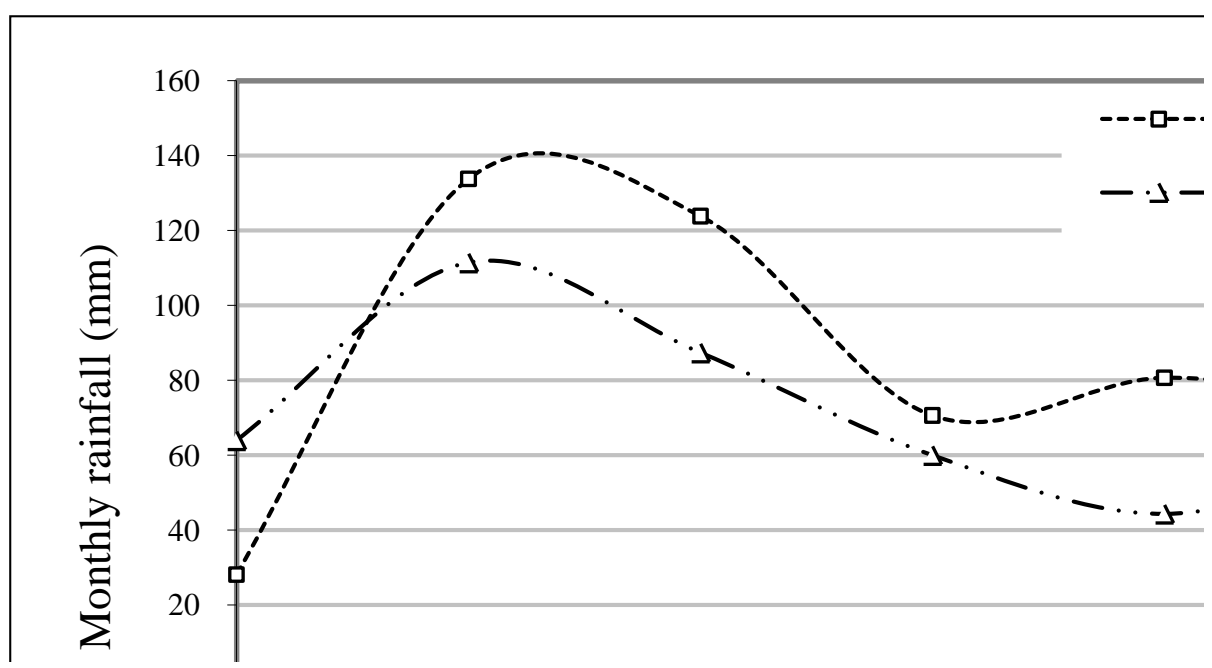

Analyses were carried out for two cuts obtained in 2016. Just before mowing, the botanical composition of the meadow was examined. The identification of species was performed according to the keys of Josifovic (1970) and Javorka and Csapody (1991).

Mowing was carried out at the stage of inflorescence appearance in the most abundant species, i.e. tall oat grass (Arrhenatherum elatius L.). Forage yield was determined by measuring the total plot biomass weight immediately after mowing. After the measurement, samples were taken for the analysis of the water content in the forage and botanical composition. The percentages, by weight, of grasses (fam. Poaceae), legumes (fam. Fabaceae) and other species in the forage were determined in the measured sample (1000 g). After drying the samples at $65^{\circ} \mathrm{C}$, hay yield $\left(\mathrm{t} \mathrm{ha}^{-1}\right)$ was calculated. The results were analyzed by the method of analyzing the variance of a single-factorial trial (ANOVA) using the SPSS 4.5 software. The significance of differences in mean values of the treatments was tested by the LSD test. 


\section{Results and discussion}

In the first cut in 2016, significantly higher forage and hay yields as compared to the control were achieved in treatment $\mathrm{A}_{1}$, in which $40 \mathrm{~kg} \mathrm{ha}^{-1} \mathrm{~N}$ was used in the spring (Table 1).

Table 1. Effect of fertilization treatments $\left(\mathrm{A}_{0}-\mathrm{A}_{3}\right)$ on forage yield, hay yield and dry matter content in the forage in the first cut of natural grassland in 2016

\begin{tabular}{|c|c|c|c|}
\hline & $\begin{array}{c}\text { Forage yield } \\
\left(\mathrm{t} \mathrm{ha}^{-1}\right)\end{array}$ & $\begin{array}{c}\text { Hay yield } \\
\left(\mathrm{t} \mathrm{ha}^{-1}\right)\end{array}$ & $\begin{array}{c}\text { Dry matter content } \\
(\%)\end{array}$ \\
\hline A0 & $12.63 \mathrm{c}$ & $3.50 \mathrm{c}$ & 23.9 \\
\hline A1 & $22.86 \mathrm{~b}$ & $5.98 \mathrm{~b}$ & 22.4 \\
\hline A2 & $31.54 \mathrm{a}$ & $8.05 \mathrm{a}$ & 23.2 \\
\hline A3 & $34.63 \mathrm{a}$ & $8.31 \mathrm{a}$ & 21.6 \\
\hline ANOVA 0,05 & $*$ & $*$ & $\mathrm{~ns}$ \\
\hline
\end{tabular}

Values followed by different small letters within columns are significantly different $(\mathrm{P}<0.05)$ according to the LSD test; ${ }^{*} \mathrm{~F}$ test significant at $\mathrm{P} \leq 0.05$; ns - non significant.

However, compared to treatments $A_{0}$ and $A_{1}$, forage and hay yields were significantly higher in treatments $A_{2}$ and $A_{3}$. Therefore, forage and hay yields increased with the increase in the amount of nitrogen applied in the spring from 40 to $80 \mathrm{~kg} \mathrm{ha}^{-1}$, but further increase in the amount of nitrogen to $120 \mathrm{~kg} \mathrm{ha}^{-1}$ led to no increasing yield trend. As found by Dubljević (2007), fertilization of natural grasslands with nitrogen results in a significant increase in forage yield and raw proteins, enhances growth and tillering of grasses, increases grass cover density, extends the growing season and slows down plant aging. Vučković et al. (2004) and Alibegović - Grbić et al. (2004) also pointed out that nitrogen has a major impact on yield, nutritional value and floral composition of highland natural grasslands. As reported by Vučković et al. (2004), grass biomass yield was increased by $153 \%$ under treatment with $160 \mathrm{~kg} \mathrm{~N} \mathrm{ha}^{-1}$ compared to control. Fertilizing grasslands with nitrogen increases carbon yield in the above-ground part, directly by entering the plant life processes (Xia and Wan 2008) and indirectly through faster mineralization of organic matter in the soil (Nowinski et al. 2008). Apart from the type and quantity of fertilizer, the yield of natural meadows is also significantly affected by the timing of fertilizer application (Lazarević et al. 2004). This is especially true for lawns at higher altitudes where regeneration possibilities after cutting are reduced. The same authors pointed out that fertilizing grasslands with nitrogen is not economically justified at altitudes above $1000 \mathrm{~m}$ a.s.l. 
Table 2. Effect of fertilization treatments $\left(\mathrm{A}_{0}-\mathrm{A}_{3}\right)$ on botanical composition (\% of legumes, grasses and other species) and hay yield of grasses, legumes and other plants in the first cut of natural grassland in 2016

\begin{tabular}{|c|c|c|c|c|c|c|}
\hline & $\begin{array}{c}\text { Percentage } \\
\text { of grasses } \\
(\%)\end{array}$ & $\begin{array}{c}\text { Percentage } \\
\text { of legumes } \\
(\%)\end{array}$ & $\begin{array}{c}\text { Percentage } \\
\text { of other } \\
\text { plants (\%) }\end{array}$ & $\begin{array}{c}\text { Yield of } \\
\text { grasses }^{\left(\mathrm{tha}^{-1}\right)}\end{array}$ & $\begin{array}{c}\text { Yield of } \\
\text { legumes } \\
\left(\mathrm{t} \mathrm{ha}^{-1}\right)\end{array}$ & $\begin{array}{c}\text { Yield of } \\
\text { other plants }^{-1} \\
\left(\mathrm{t} \mathrm{ha}^{-1}\right)\end{array}$ \\
\hline A0 & $69.6 \mathrm{~b}$ & 2.9 & $27.5 \mathrm{a}$ & $2.47 \mathrm{c}$ & 0.088 & $0.942 \mathrm{a}$ \\
\hline A1 & $87.9 \mathrm{a}$ & 0.8 & $11.3 \mathrm{~b}$ & $5.27 \mathrm{~b}$ & 0.052 & $0.658 \mathrm{~b}$ \\
\hline A2 & $97.2 \mathrm{a}$ & 0.1 & $2.7 \mathrm{c}$ & $7.83 \mathrm{a}$ & 0.009 & $0.217 \mathrm{c}$ \\
\hline A3 & $96.6 \mathrm{a}$ & 0.1 & $3.3 \mathrm{c}$ & $8.02 \mathrm{a}$ & 0.009 & $0.284 \mathrm{c}$ \\
\hline $\begin{array}{c}\text { ANOVA } \\
0,05\end{array}$ & $*$ & $\mathrm{~ns}$ & $*$ & $*$ & $\mathrm{~ns}$ & $*$ \\
\hline
\end{tabular}

Values followed by different small letters within columns are significantly different $(\mathrm{P}<0.05)$ according to the LSD test; ${ }^{*} \mathrm{~F}$ test significant at $\mathrm{P} \leq 0.05$; ns - non significant.

In all fertilized treatments in the first cut, the percentage of grasses was significantly higher than in the control (Table 2). The percentage of legumes was low and did not change significantly across fertilization treatments, while the percentage of other plant species was decreased with increasing fertilizer rate. Fertilization had a similar effect on the yield of grasses, legumes and other plants. Nešić et al. (2004), Stevanović et al. (2004), Stevens et al. (2004) and Vučković et al. (2004) showed that fertilization can significantly increase dry matter yield and quality of natural grasslands and change their floral composition. Fertilization of natural grasslands with nitrogen reduces plant diversity and the presence of legumes and $\mathrm{C}_{4}$ plants, while increasing the presence of $\mathrm{C}_{3}$ plants (Gough et al. 2000; Stevens et al. 2004). This phenomenon is the result of increased competition for light of the plants (Xia and Wan, 2008).

In this experiment, a total of 50 different plant species of 44 genera and 20 families (Table 3) were identified in the grassland. The most common was the Poaceae family, dominated by the species Arrhenatherum elatius, which forms a typical community Arrhenatherion elatiorius. 
Table 3. Plant species in the grassland

\begin{tabular}{|c|c|c|}
\hline Poaceae & Fabaceae & $\begin{array}{l}\text { Caryophyllaceae } \\
\text { Dianthus }\end{array}$ \\
\hline Arrhenatherum elatius & Lotus corniculatus & deltoideus \\
\hline Agrostis capilaris & Trifolium campestre & Silene sendtneri \\
\hline Briza media & Trifolium montanum & $\begin{array}{l}\text { Silene vulgaris } \\
\text { Stellaria }\end{array}$ \\
\hline Cynosurus cristatus & Trifolium pratense & graminea \\
\hline Dactylis glomerata & Vicia cracca & Viscaria vulgaris \\
\hline Holcus lanatus & Rosaceae & Rubiaceae \\
\hline Phleum pratense & Alchemilla vulgaris & Cruciata glabra \\
\hline Asteraceae & Filipendula vulgaris & Galium verum \\
\hline Centaurea jacea & Fragaria vesca & Apiaceae \\
\hline Crepis biennis & Geum urbanum & Astrantia major \\
\hline Leucanthemum ircutianum & Potentilla erecta & $\begin{array}{l}\text { Myrrhis odorata } \\
\text { Tanacetum }\end{array}$ \\
\hline Telecia speciosa & Porentilla recta & macrophyllum \\
\hline Tragopogon pratensis & Lamiaceae & $\begin{array}{l}\text { Primulaceae } \\
\text { Lysimachia }\end{array}$ \\
\hline Campanulaceae & Clinopodium vulgare & $\begin{array}{l}\text { nummularia } \\
\text { Lysimachia }\end{array}$ \\
\hline Campanula patula & Salvia verticillata & punctata \\
\hline Geraniaceae & Cyperaceae & $\begin{array}{l}\text { Scrophulariaceae } \\
\text { Rhinanthus }\end{array}$ \\
\hline Geranium molle & Carex spicata & $\begin{array}{l}\text { rumelicus } \\
\text { Verbascum }\end{array}$ \\
\hline Hypericaceae & Cistaceae & nigrum \\
\hline Hypericum perforatum & Helianthemum nummularium & Polygonaceae \\
\hline Dipsacaceae & Juncaceae & Rumex acetosa \\
\hline Knautia arvensis & Juncus articulatus & Rumex crispus \\
\hline Malvaceae & Liliaceae & \\
\hline Malva moshata & Veratrum album & \\
\hline
\end{tabular}

In the second cut, forage and hay yields were lower than in the first one. The reason for this, among other things, was a smaller amount of precipitation in the second part of the growing season. At that time, only $\mathrm{A}_{1}$ treatment showed significantly higher forage and hay yields than the control (Table 4). A significantly higher content of dry matter in forage was recorded only in treatment $\mathrm{A}_{3}$ in relation to the control. 
Table 4. Effect of fertilization treatments $\left(\mathrm{A}_{0}-\mathrm{A}_{3}\right)$ on forage yield, hay yield and dry mater content in the forage in the second cut of natural grassland in 2016

\begin{tabular}{|c|c|c|c|}
\hline & $\begin{array}{c}\text { Forage yield } \\
\left(\mathrm{t} \mathrm{ha}^{-1}\right)\end{array}$ & $\begin{array}{c}\text { Hay yield } \\
\left(\mathrm{t} \mathrm{ha}^{-1}\right)\end{array}$ & $\begin{array}{c}\text { Dry matter content } \\
(\%)\end{array}$ \\
\hline A0 & $10.64 \mathrm{ab}$ & $3.84 \mathrm{~b}$ & $21.1 \mathrm{~b}$ \\
\hline A1 & $11.54 \mathrm{a}$ & $4.89 \mathrm{a}$ & $33.1 \mathrm{ab}$ \\
\hline A2 & $9.42 \mathrm{~b}$ & $3.90 \mathrm{~b}$ & $36.3 \mathrm{ab}$ \\
\hline A3 & $9.66 \mathrm{~b}$ & $4.41 \mathrm{ab}$ & $39.1 \mathrm{a}$ \\
\hline ANOVA 0,05 & $*$ & $*$ & $*$ \\
\hline
\end{tabular}

Values followed by different small letters within columns are significantly different $(\mathrm{P}<0.05)$ according to the LSD test; ${ }^{*} \mathrm{~F}$ test significant at $\mathrm{P} \leq 0.05$.

The percentage of grasses in the second cut was significantly higher in treatment $A_{1}$ than in the control, and in treatments $A_{2}$ and $A_{3}$ than in the previous two (Table 5). The percentage of legumes was higher than in the first cut, and decreased with increasing fertilizer rate. The percentage of other plants was $84 \%$ higher in the second cut than in the first cut, and significantly decreased with increasing fertilizer rate. Grass yield was significantly higher in all treatments as compared to the control, while yield of legumes and weeds decreased significantly with increasing fertilization rate.

Table 5. Effect of fertilization treatments $\left(\mathrm{A}_{0}-\mathrm{A}_{3}\right)$ on botanical composition (\% of legumes, grasses and other species) and hay yield of grasses, legumes and other plants in the second cut of natural grassland in 2016

\begin{tabular}{|c|c|c|c|c|c|c|}
\hline & $\begin{array}{c}\text { Percentage } \\
\text { of grasses } \\
(\%)\end{array}$ & $\begin{array}{c}\text { Percentage } \\
\text { of } \\
\text { legumes } \\
(\%)\end{array}$ & $\begin{array}{l}\text { Percentage } \\
\text { of other } \\
\text { plants (\%) }\end{array}$ & $\begin{array}{l}\text { Yield of } \\
\text { grasses } \\
\left.(\mathrm{t} \mathrm{ha})^{-1}\right)\end{array}$ & $\begin{array}{l}\text { Yield of } \\
\text { legume } \\
\left.(\mathrm{t} \mathrm{ha})^{-1}\right)\end{array}$ & $\begin{array}{c}\text { Yield of } \\
\text { other } \\
\text { plants } \\
\left(\mathrm{t} \mathrm{ha}^{-1}\right)\end{array}$ \\
\hline A0 & $45.1 \mathrm{c}$ & $4.25 \mathrm{a}$ & $50.7 \mathrm{a}$ & $1.743 \mathrm{~b}$ & $0.162 \mathrm{a}$ & $1.938 \mathrm{a}$ \\
\hline A1 & $78.6 \mathrm{~b}$ & $2.31 \mathrm{~b}$ & $19.1 \mathrm{~b}$ & $3.854 \mathrm{a}$ & $0.106 \mathrm{~b}$ & $0.927 \mathrm{~b}$ \\
\hline A2 & $96.0 \mathrm{a}$ & $0.19 \mathrm{c}$ & $3.8 \mathrm{c}$ & $3.752 \mathrm{a}$ & $0.007 \mathrm{c}$ & 0.137 c \\
\hline A3 & $94.8 \mathrm{a}$ & $0.35 \mathrm{c}$ & $4.9 \mathrm{c}$ & $4.194 \mathrm{a}$ & $0.014 \mathrm{c}$ & 0.198 c \\
\hline $\begin{array}{c}\text { ANOVA } \\
0,05\end{array}$ & $*$ & $*$ & $*$ & $*$ & $*$ & $*$ \\
\hline
\end{tabular}

Values followed by different small letters within columns are significantly different $(\mathrm{P}<0.05)$ according to the LSD test; ${ }^{*} \mathrm{~F}$ test significant at $\mathrm{P} \leq 0.05$. 


\section{Conclusion}

In the first cut, significantly higher forage and hay yields, as compared to the control, were reported in all fertilizing treatments and the highest yield was achieved in treatments $A_{2}$ and $A_{3}$. In the second cut, significantly higher forage and hay yields were reported only in treatment $\mathrm{A} 1$, as compared to the control. Therefore, forage and hay yield increased with the increase in the amount of nitrogen used in the spring from 40 to $80 \mathrm{t} \mathrm{ha}^{-1}$, but further increase in the nitrogen amount up to $120 \mathrm{t} \mathrm{ha}^{-1}$ resulted in the absence of the yield increasing trend. In the first cut, fertilization caused no change in the content of dry matter in the forage, while in the second cut a positive effect was achieved. In the second cut, forage and hay yields were significantly lower than in the first one.

A total of 50 different plant species of 44 genera and 20 families were identified in the grassland. In the first and second cut, in all fertilized treatments, the percentage of grasses was significantly higher than in the control. The percentage of legumes in the first cut was low, while in the second cut it decreased significantly with increasing fertilizer rate. The percentage of other plants was higher in the second cut than in the first one, and significantly decreased in both cuts with increasing fertilizer rate.

\section{Acknowledgements}

This work is part of the research project Ref. No. TR-31016, funded by the Ministry of Education, Science and Technological Development, Republic of Serbia.

\section{References}

Alibegović-Grbić S., Čivić H., Bezdrob M. (2004): The influence of the use of lower nitrogen and plant development stages in mowing on the yield of dry matter and crude proteins from the grassland. Acta Agriculturae Serbica, 17: 497-293.

Djukić D., Stevovic V., Đurovic D., Ilic O. (2008): The effect of organic fertilizer on biomass yield and quality of natural meadows. Options mediterraneennes, Sustainable Mediterranean Grasslands and their Multi-Functions, 78: 431-434.

Dubljević R. (2007): The influence of nitrogen fertilization on the production characteristics of Agroseietum vulgaris meadows in the hilly area of the Polimlje. Proceedings, XI Symposium on Forage Crops of the Republic of Serbia, Novi Sad, Serbia, 44 (1): 355-360.

Frink C.R., Waggoner P.E., Ausubel J.H. (1999): Nitrogen fertilizer: retrospect and prospect. PNAS, 96: 1175-1180.

Gough L., Osenberg C.W., Gross K.L., Collins S.L. (2000): Fertilization effects on species density and primary productivity in herbaceous plant communities. Oikos, 89: 428-439.

Javorka S., Csapody V. (1991): Iconographia florae partis austro-orientalis Europae Centralis. Akadémiai Kiadó, Budapest. 
Josifović M. (1970): Flora SR Srbije I-X. SANU, Department of Natural Sciences and Mathematics, Belgrade.

Lazarević D., Stošić M., Dajić Z., Terzić D., Cvetković M. (2009): Productivity and quality of plant mass of meadow ass. Danthonietum calycinae depending on the fertilization and utilization time. Biotechnology in Animal Husbandry, 25 (1-2): 133-142.

Lazarević D., Stošić M., Dinić B., Terzić D., Lugić Z. (2004): Production and quality of plant mass of natural lawn ass. Danthonietum calycinae on Kopaonik. Acta Agriculturae Serbica, 17: 273-278.

LeBauer D.S., Treseder K.K. (2008): Nitrogen limitation of net primary productivity in terrestrial ecosystems is globally distributed. Ecology, 89: 371-379.

Nešić Z., Tomić Z., Mrfat-Vukelić S., Žujović M. (2004): The quality of natural grasslands in the area of Stara Planina. Acta Agriculturae Serbica, 17: 243-247.

Nowinski N.S., Trumbore S.E., Schuur E., Mack M.C., Shaver G.R. (2008): Nutrient addition prompts rapid destabilization of organic matter in an arctic tundra ecosystem. Ecosystems, 11: 16-25.

RZS (2013): Agricultural Survey 2012: Agriculture in the Republic of Serbia. Republic Statistical Office of Serbia, p. 62.

SGS (2015): Statistical Yearbook of Serbia. Republic Statistical Office of Serbia, p. 232.

SPSS 4.5 Inc. (1993): STATISTICA for Windows (Computer program manual).Tulsa.

Stevanović D., Jakovljević M., Vrbničanin S., Aćić S. (2004): Chemical composition of the hay of natural grasslands of Zlatibor depending on the composition of the soil. Acta Agriculturae Serbica, 17: 235-241.

Stevens C.J., Dise N.B., Moutford J.O., Gowing D.J. (2004): Impact of nitrogen deposition on the species richness of grasslands. Science, 303: 1876-1879.

Vitousek P.M., Howarth R.W. (1991): Nitrogen limitation on land and in the sea: how can it occur. Biogeochemistry, 13: 87-115.

Vučković S., Simić A., Ćupina B., Stojanović I., Stanisavljević R., Vojin S., Dubljević R. (2004): The effect of nitrogen fertilization on the productivity of Cynosuretum crystals on the Sjenica-Pešter plateau. Acta Agriculturae Serbica, 17: 279-287.

Xia J.Y., Wan S.Q. (2008): Global response patterns of terrestrial plant species to nitrogen addition. New Phytol., 179:428-439.

You C., Wu F., Gan Y., Yang W., Hu Z., Xu Z., Tan B., Liu L., Ni X. (2017): Grass and forbs respond differently to nitrogen addition: a meta-analysis of global grassland ecosystems. Scientific Reports, 7: 1563. 


\title{
PRODUKTIVNOST PRIRODNOG TRAVJAKA REDA ARRHENATHERETALIA U ZAVISNOSTI OD RAZLIČITIH NIVOA ĐUBRENJA AZOTOM
}

\section{Dalibor Tomić1, Duško Brković ${ }^{1}$, Vladeta Stevović ${ }^{1}$, Nikola Bokan ${ }^{1}$, Dragan Đurović ${ }^{1}$, Đorđe Lazarević ${ }^{1}$}

${ }^{1}$ Univerzitet u Kragujevcu, Agronomski fakultet u Čačku, Cara Dušana 34,

\author{
Čačak, Srbija
}

\begin{abstract}
Rezime
Prirodni travnjaci predstavljaju značajan resurs u proizvodnji kabaste stočne hrane u brdsko-planinskom području Srbije. Pravilnom primenom mineralnih đubriva na ovim travnjacima je moguće višestruko povećati proizvodnju. U radu je analiziran uticaj primene NPK đubriva sa različitim nivoima azota (neđubreno - $\mathrm{A}_{0}$; N60:P40:K40 - $\mathrm{A}_{1}$; N100:P40:K40 - $\mathrm{A}_{2}$; N140:P40:K40 - $\mathrm{A}_{3}$ ) na prinos krme i botanički sastav prirodnog travnjaka reda Arrhenatheretalia na padinama planine Kopaonik. Sa povećanjem količine primenjenog azota u proleće sa 40 na $80 \mathrm{~kg} \mathrm{ha}^{-1}$ rastao je i prinos krme i sena, da bi, sa daljim povećanjem količine azota na $120 \mathrm{~kg} \mathrm{ha}^{-1}$, trend povećanja prinosa izostao. U drugom otkosu je zabeležen manji prinos krme i sena u odnosu na prvi. Na travnjaku je determinisano ukupno 50 različitih biljnih vrsta iz 44 roda i 20 familija. U oba otkosa, na svim đubrenim tretmanima, udeo trava je bio značajno veći u odnosu na kontrolu. Udeo leguminoza u prvom otkosu je bio nizak, dok se u drugom otkosu sa porastom nivoa đubriva značajno smanjivao. Udeo ostalih biljaka je u drugom otkosu bio veći u odnosu na prvi i sa povećanjem norme đubriva značajno se smanjivao u oba otkosa.
\end{abstract}

Ključne reči: botanički sastav, đubrenje, prirodni travnjak, prinos krme 